University of Wollongong

Research Online

Faculty of Engineering and Information

Faculty of Engineering and Information

Sciences - Papers: Part A

Sciences

2017

Superior mechanical properties of microalloyed steels processed via a new technology based on austenite conditioning followed by warm deformation

Andrii Kostryzhev

University of Wollongong, andrii@uow.edu.au

Olexandra Marenych

University of Wollongong, marenych@uow.edu.au

Follow this and additional works at: https://ro.uow.edu.au/eispapers

Part of the Engineering Commons, and the Science and Technology Studies Commons

Research Online is the open access institutional repository for the University of Wollongong. For further information contact the UOW Library: research-pubs@uow.edu.au 


\title{
Superior mechanical properties of microalloyed steels processed via a new technology based on austenite conditioning followed by warm deformation
}

\author{
Abstract \\ In this paper we introduce the $A C^{2}$ WD-technology, which stands for Austenite Conditioning - Accelerated \\ Cooling - Warm Deformation. This technology was tested in laboratory conditions using a Gleeble \\ thermomechanical simulator. Two microalloyed steels processed via this technology have shown a \\ superior combination of mechanical properties, compared to those obtained via the conventional \\ thermomechanical processing routes. \\ Disciplines \\ Engineering | Science and Technology Studies \\ Publication Details \\ Kostryzhev, A. G. \& Marenych, O. O. (2017). Superior mechanical properties of microalloyed steels \\ processed via a new technology based on austenite conditioning followed by warm deformation. \\ Materials Science and Engineering A, 688 16-19.
}

This journal article is available at Research Online: https://ro.uow.edu.au/eispapers/6581 


\title{
Superior mechanical properties of microalloyed steels processed via a new technology based on austenite conditioning followed by warm deformation
}

\author{
A.G. Kostryzhev* and O.O. Marenych \\ School of Mechanical, Materials and Mechatronic Engineering, \\ University of Wollongong, NSW 2500, Australia \\ *corresponding author \\ andrii@uow.edu.au,om753@uowmail.com.au,
}

\begin{abstract}
In this paper we introduce the $\mathrm{AC}^{2} \mathrm{WD}$-technology, which stands for Austenite Conditioning Accelerated Cooling - Warm Deformation. This technology was tested in laboratory conditions using a Gleeble thermomechanical simulator. Two microalloyed steels processed via this technology have shown a superior combination of mechanical properties, compared to those obtained via the conventional thermomechanical processing routes.
\end{abstract}

Key words: microalloyed steel, thermomechanical processing, microstructure, mechanical properties

Manufacturing of high strength steels is usually performed on multi-stand rolling mills using continuously cast slabs of up to $250 \mathrm{~mm}$ thickness. Due to high energy consumption, this technology is economically viable at high production capacity (millions of tons per year). With growing competition on the global steel markets the companies are searching for opportunities to reduce manufacturing costs, broaden the product nomenclature and keep the quality high. To reduce the product cost two major solutions can be suggested: (i) simplify a steel chemical composition; in the case of high strength steels this would mean a decrease in number and contents of microalloying elements; and (ii) simplify a processing route, in particular, decrease the number of hot deformation stages. Significant steps in this direction have been made during last 20 years. Compared to the conventional $15-20$ pass rolling of $\approx 250 \mathrm{~mm}$ thick continuously cast slabs, the Compact Strip Production (CSP) technology utilises 5-6 rolling passes of $\approx 50 \mathrm{~mm}$ thick slabs, and in the Strip Casting technology only 1 rolling pass is applied to the $2-3 \mathrm{~mm}$ thick cast strip. Although the CSP technology allows manufacturing of various steel grades [1-4], the strip casting technology is currently limited to commercial manufacturing of plain carbon, silicon steels and stainless steels [5,6]. Recent experiments conducted in laboratory showed a possibility to produce thin cast dual phase and TRIP steels completely eliminating the hot deformation stage and applying only a short heat treatment procedure $[7,8]$. However, a decrease in amount of hot deformation increases the prior austenite grain size and grain size of low temperature phases (ferrite, bainite, martensite). These may result in decreased ductility, in particular, with increasing strength [9]. Thus, we suggest that hot deformation strain must be kept above certain limits. These limits will vary with steel grade, chemical composition, expected phase balance and a required combination of mechanical properties.

In this work we propose a new processing technology, which consists of 2-3 deformation stages and has a potential to produce steels of a simplified chemical composition with simultaneously high strength and ductility. The first and second deformation stages will assure the "Austenite Conditioning". On the first stage, deformation should be carried out at a temperature above the recrystallization stop temperature $\left(\mathrm{T}_{\mathrm{nr}}\right)$ to a strain value equal or above the critical strain required to initiate dynamic recrystallization (DRX). On the second stage, deformation should be 
carried out at a temperature near or below $\mathrm{T}_{\mathrm{nr}}$ to a strain value which will assure formation of retained crystal structure defects (dislocations, shear bands, low angle boundaries). After austenite conditioning the "Accelerated Cooling" to a temperature below the austenite to ferrite transformation finish temperature $\left(\mathrm{A}_{1}\right)$ will help to form a fine grained microstructure. The phase balance after cooling may vary with respect to steel composition, cooling rate value and cooling stop temperature. On the third stage, the "Warm Deformation" at cooling stop temperature (or below it) will increase the steel strength via work hardening. Following the deformation, holding at a temperature below $\mathrm{A}_{1}$ may provide an opportunity for precipitation strengthening (depending on steel composition).

The $\mathrm{AC}^{2} \mathrm{WD}$-technology was tested in laboratory conditions on two steels $0.095 \mathrm{C}, 1.3 \mathrm{Mn}$, $0.26 \mathrm{Si}, 0.018 \mathrm{Ni}, 0.013 \mathrm{Cr}, 0.022 \mathrm{Cu}, 0.039 \mathrm{Al}, 0.012 \mathrm{Ti}, 0.001 \mathrm{~S}, 0.012 \mathrm{P}$, and $0.0043 \mathrm{~N}$ (wt. \%), denoted below as Ti-steel, and $0.081 \mathrm{C}, 1.20 \mathrm{Mn}, 0.27 \mathrm{Si}, 0.021 \mathrm{Ni}, 0.019 \mathrm{Cr}, 0.1 \mathrm{Mo}, 0.016 \mathrm{Cu}$, 0.037 Al, 0.064Nb, 0.021 Ti, 0.001S, 0.012P, and 0.0047N (wt. \%), denoted below as NbTi-steel. The steels were commercially produced by BlueScope Steel Ltd, Australia, and provided in the form of 10x15x20 mm size samples cut from a quarter-thickness position of a $230 \mathrm{~mm}$ thick continuously cast slab. The processing was carried out using a Gleeble 3500 thermomechanical simulator. Two processing schedules were applied to each of two steels (Figure 1): without holding after warm deformation or with holding.

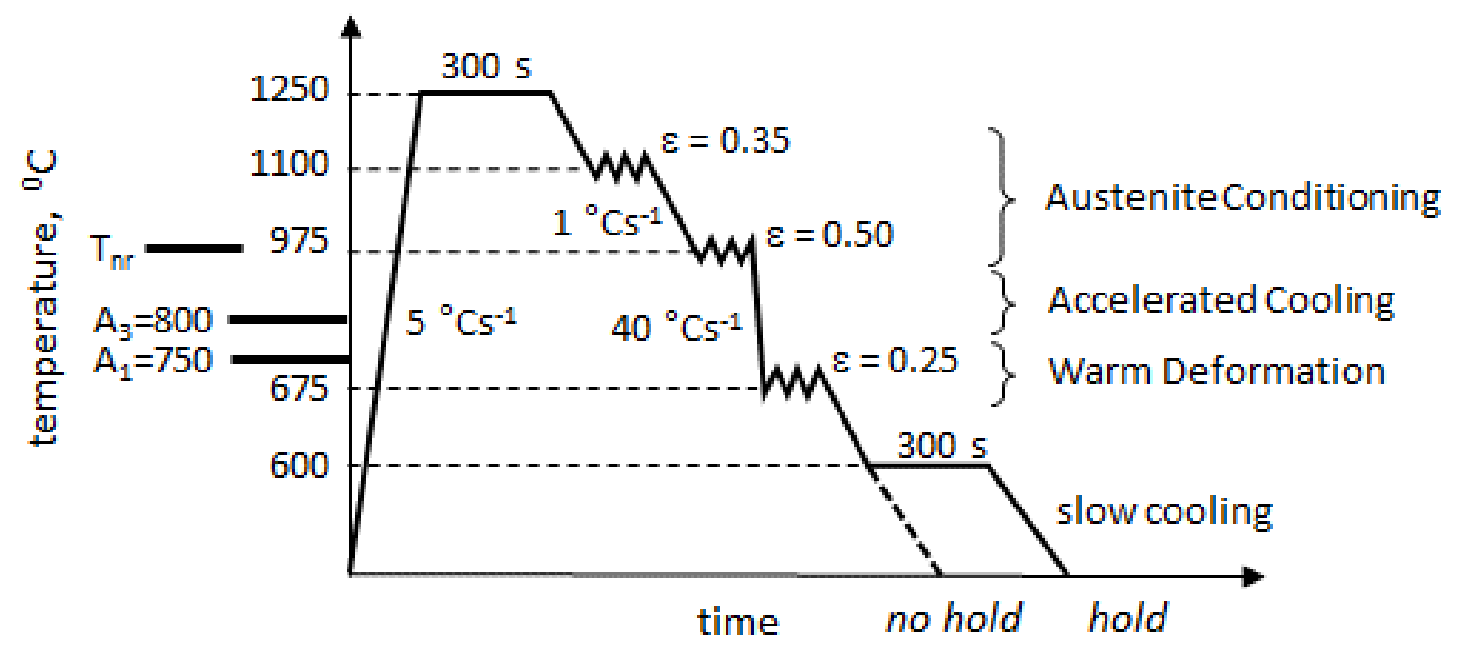

Figure 1. Schematic presentation of the $\mathrm{AC}^{2} \mathrm{WD}$ processing schedule

The processing involved:

- austenitising at $1250{ }^{\circ} \mathrm{C}$ for $300 \mathrm{~s}$, followed by cooling to $1100{ }^{\circ} \mathrm{C}$ at a cooling rate of $1{ }^{\circ} \mathrm{Cs}^{-1}$; this reheating procedure was used in accordance with the previous study on $\mathrm{NbTi}$-steel [10] in order to compare the previous and current results;

- first deformation at $1100{ }^{\circ} \mathrm{C}$ to 0.35 strain at $5 \mathrm{~s}^{-1}$ strain rate; this temperature was chosen to be well above $\mathrm{T}_{\mathrm{nr}}$ for the studied steels, which is $900{ }^{\circ} \mathrm{C}$ and $975{ }^{\circ} \mathrm{C}$ for the Ti- and NbTi-steels, respectively [11];

- second deformation at $975{ }^{\circ} \mathrm{C}$ to 0.50 strain at $5 \mathrm{~s}^{-1}$ strain rate, these parameters had to allow complete DRX in the Ti-steel and partial recrystallization in the NbTi-steel [12];

- cooling to $675{ }^{\circ} \mathrm{C}$ at a cooling rate of $40{ }^{\circ} \mathrm{Cs}^{-1}$; this temperature was chosen to be below $\mathrm{A}_{1} \approx$ $750{ }^{\circ} \mathrm{C}$ for both steels, and the cooling rate had to assure retention of deformed microstructure after the second deformation and prevention of pearlite formation;

- third deformation at $675^{\circ} \mathrm{C}$ to 0.25 strain at $5 \mathrm{~s}^{-1}$ strain rate gave sufficient work hardening;

- holding at $600{ }^{\circ} \mathrm{C}$ for $300 \mathrm{~s}$ was supposed to promote $\mathrm{Nb}$ precipitation in the NbTi-steel [1317] and, possibly, facilitate the TiC precipitation in the Ti-steel [18-20]; to verify the effect of 
holding on microstructure and mechanical properties, a schedule without holding was also tested.

General microstructure characterisation for the four studied conditions was carried out using optical and scanning electron microscopy. Optical microscopy was conducted on a Leica DM6000M microscope equipped with Leica Application Suite (LAS) 4.0.0 image processing software. Scanning electron microscopy was carried out using a JEOL 7001F FEG scanning electron microscope (SEM) operating at $10 \mathrm{kV}$. Optical and SEM sample preparation included polishing with $\mathrm{SiC}$ papers and diamond suspensions followed by etching with $5 \%$ Nital. For determination of particle size distributions, number density and volume fraction values, near 100 and 550 particles were measured in the NbTi- and Ti-steels, respectively. The energy dispersive X-ray spectroscopy (EDS) semi-quantitative point analysis of precipitates was carried out using an AZtec 2.0 Oxford SEM EDS system. For determination of particle compositions, 45-50 particles were analysed for each condition.

Tensile testing for the four studied conditions was carried out on a Kammrath and Weiss $\mathrm{GmbH}$ tensile stage. Testing was performed using $2 \mathrm{~mm}$ wide, $0.8 \mathrm{~mm}$ thick and $5 \mathrm{~mm}$ gauge length flat specimens. The specimens were cut in the plane parallel to the compression direction perpendicular to the Gleeble anvil plane. Such a cutting method assured the tensile direction being parallel to the one which represents the rolling direction in Gleeble simulation. The constant crosshead speed of $5 \mu \mathrm{ms}^{-1}$ was applied and resulted in $1 \times 10^{-3} \mathrm{~s}^{-1}$ strain rate. Two specimens were tested for each condition.

Optical microscopy has revealed ferrite-pearlite microstructure in the Ti-steel (Figure 2a,b) and granular bainite microstructure in the NbTi-steel (Figure 2d,e). Formation of the bainite microstructure in the NbTi-steel can be related to increased contents of Mo and $\mathrm{Nb}$ in this steel. Molybdenum is well known for its ability to promote bainite formation [21,22]. Recent studied has shown that $\mathrm{Nb}$ can also decrease the austenite to ferrite transformation temperature and stimulate bainite formation [23-26]. In the Ti-steel processed without holding, the ferrite grain size was measured to be 3-24 $\mu \mathrm{m}$ with the average value of $10 \mu \mathrm{m}$. The overall majority of grains exhibited deformation bands running at a distance of 200-600 $\mathrm{nm}$ from each other. The average size and area fraction of second phase (pearlite) regions were $3.0 \mu \mathrm{m}$ and $2.5 \%$, respectively. Holding at $600{ }^{\circ} \mathrm{C}$ for $300 \mathrm{~s}$ did not affect the ferrite grain size, pearlite grain size and area fraction, and the distribution of deformation bands in the Ti-steel. The observed pearlite fraction was about 4 times lower than that calculated using the lever rule $(10.9 \%)$. This indicates supersaturation of the ferritic matrix with carbon, which enhances solid solution strengthening and precipitation strengthening. In the NbTi-steel processed without holding, the size of bainite grain (ferritic area surrounded by high angle boundaries) was measured to be $1-10 \mu \mathrm{m}$ with the average value of 5 $\mu \mathrm{m}$. Some grains exhibited deformation bands running at a distance of 200-400 nm from each other. The average size and area fraction of second phase, martensite/austenite (M/A) constituent, regions were $1 \mu \mathrm{m}$ and $5.5 \%$, respectively. Holding did not affect the bainite grain size and M/A parameters in the NbTi-steel.

SEM has shown the presence of 20-60 $\mathrm{nm}$ and 20-80 $\mathrm{nm}$ precipitates in the Ti-steel and NbTisteel, respectively (Figure $2 \mathrm{c}, \mathrm{f}$ ). The particles were cuboidal TiN and TiCN, and spherical TiC in the Ti-steel, and cuboidal TiNbCN and spherical $\mathrm{NbC}$ in the NbTi-steel (Figure 2g-i). The particle parameters varied with steel composition and holding at $600{ }^{\circ} \mathrm{C}$. In the Ti-steel during holding: (i) the particle number density significantly increased from 5.8 to $20.1 \mu \mathrm{m}^{-2}$; (ii) the average particle size marginally decreased from 26 to $24 \mathrm{~nm}$; and (iii) the amount of TiC (to the total amount of particles analysed) increased from 31 to $41 \%$. In the NbTi-steel during holding: (i) the particle number density slightly increased from 0.7 to $0.9 \mu \mathrm{m}^{-2}$; (ii) the average particle size significantly decreased from 60 to $37 \mathrm{~nm}$; and (iii) the amount of $\mathrm{NbC}$ (to the total amount of particles analysed) increased from 0 to $19 \%$. Upon these measurements a number of important conclusions can be made: 
1. Particle precipitation, $\mathrm{TiC}$ in the Ti-steel and $\mathrm{NbC}$ in the NbTi-steel, does happen during holding at $600{ }^{\circ} \mathrm{C}$. This corresponds to earlier published results [13-20];

2. Growth of $\mathrm{TiC}$ particles in the Ti-steel is occurring at a much faster rate than this of $\mathrm{NbC}$ particles in the NbTi-steel. Obviously in the NbTi-steel, some $\mathrm{Nb}$ was consumed by large TiNbCN particles precipitating in austenite, leaving less $\mathrm{Nb}$ available for $\mathrm{NbC}$ precipitation in bainite;

3. The particle number density in SEM visible size range $(>20 \mathrm{~nm})$ is much lower in the NbTisteel compared to the Ti-steel. This leads to the expectation of a higher number density of $<20$ $\mathrm{nm}$ particles in the NbTi-steel compared to the Ti-steel, which requires further investigation.
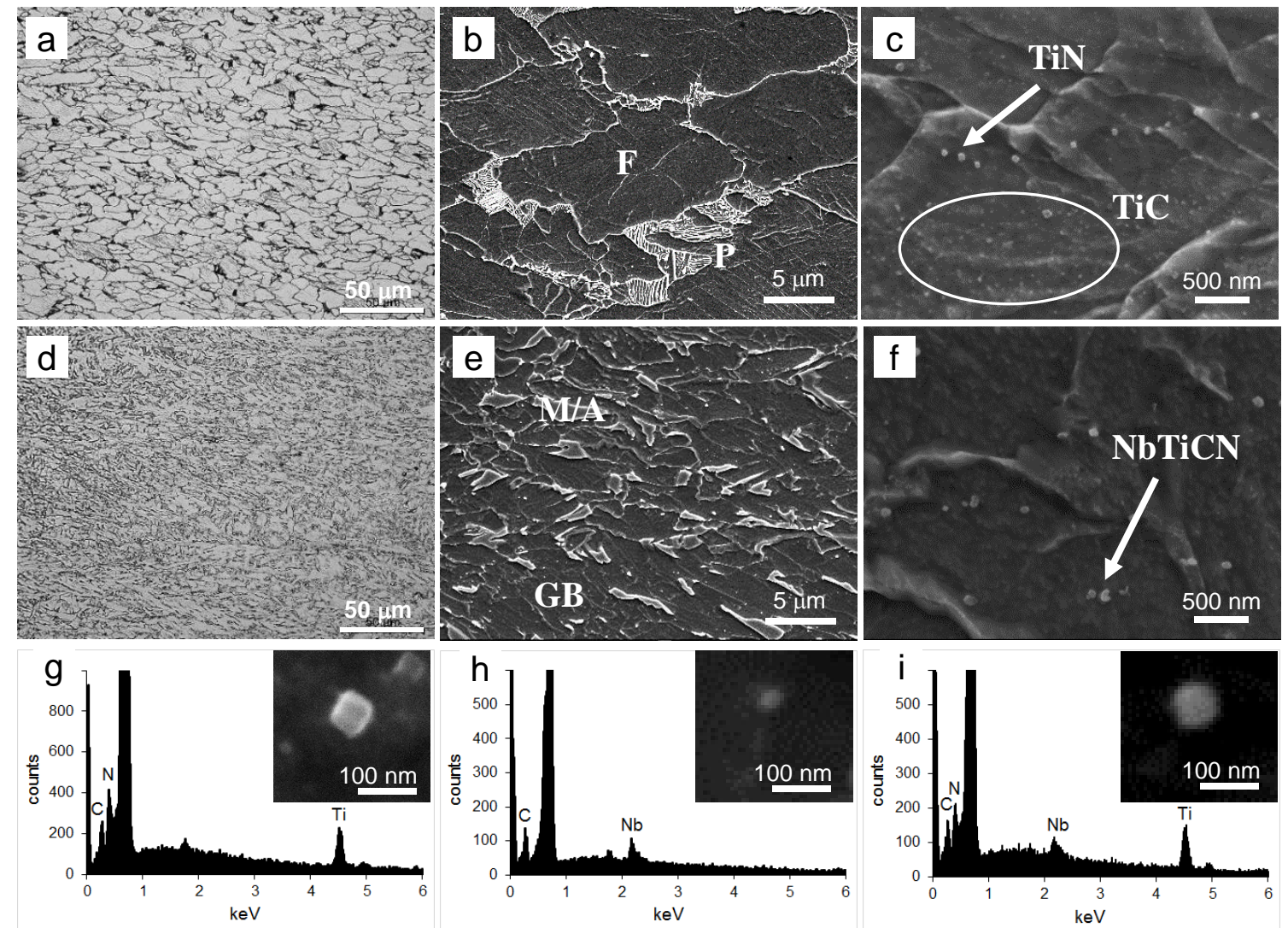

Figure 2. Selected (a, d) optical images of grain structure, (b, e) SEM images of grain structure, (c, f) SEM images of microalloying element precipitates, and EDS spectra of (g) Ti-rich, (h) Nbrich and (i) NbTi-rich particles in the (a,b,c,g) Ti-microalloyed steel after holding and (d,e,f,h,i) NbTi-microalloyed steel after holding

Ambient temperature mechanical properties of the two studied steels in two processing conditions are presented in Figure 3 and Table 1. In the Ti-steel, the yield stress (YS), ultimate tensile strength (UTS) and elongation to failure (El) were measure to be 627-686 MPa, 771-783 $\mathrm{MPa}$ and 24-27\%, respectively, depending on presence or absence of holding. In the NbTi-steel, YS, UTS and El were 820-880 MPa, 993-1037 MPa and 21-24\%, respectively. As expected, the NbTi-steel showed higher YS and UTS values than the Ti-steel. This can be related to a number of microstructural differences: bainitic microstructure (smaller grain size and higher dislocation density) in the NbTi-steel in contrast to a ferritic-pearlitic one (larger grain size and lower dislocation density) in the Ti-steel; a 2 times higher second phase fraction in the NbTi-steel; and a presumably higher number density of $<20 \mathrm{~nm}$ particles in the NbTi-steel. In both steels the strength increased during holding due to precipitation strengthening. However, the two steels exhibited 
opposite trends in the elongation variation during holding: El decreased in the Ti-steel and increased in the NbTi-steel. In the Ti-steel a decrease in elongation coincided with an increase in strength. In the NbTi-steel the dislocation annihilation during holding could result in an increased density of free dislocations and enhanced slip during room temperature straining. In addition, a higher number density of fine precipitates might have increased the dislocation generation rate during testing. Dislocations pinned by fine nanosized particles were suggested to become dislocation generation sources [27, 28].

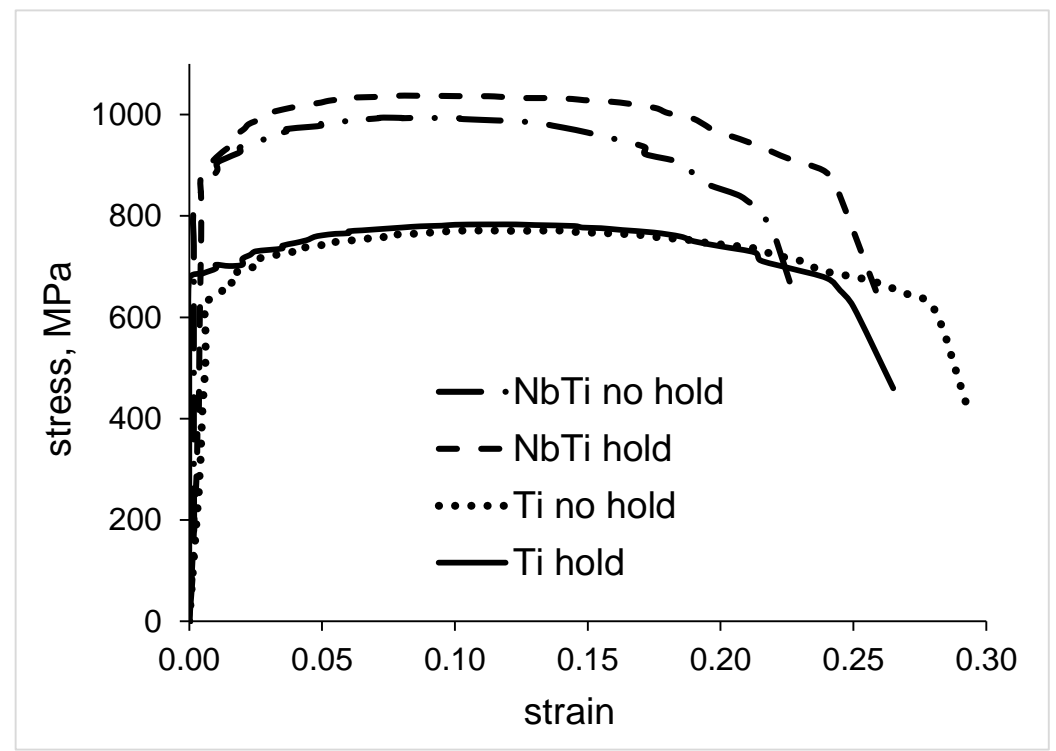

Figure 3. Tensile stress-strain curves of the two studied steels in two processing conditions

Comparison of mechanical properties obtained in this work to those after contemporary processing showed significant advantages of the $\mathrm{AC}^{2} \mathrm{WD}$-technology. For the Ti-steel, similar or slightly higher strength and ductility were obtained here for up to 6.6 times lower Ti content in steel composition after a more simple processing schedule, namely reduced number of deformation passes (compare this work with [29, 31] in Table 1). For the same number of deformation passes, the $\mathrm{AC}^{2} \mathrm{WD}$-technology resulted in 150-200 MPa higher YS and UTS with similar El for a 5 times lower Ti content (compare this work with [30] in Table 1). For the NbTi-steel, accelerated cooling followed by warm deformation resulted in about 2 times higher YS and UTS for the same total strain (compare this work with our previous work on the NbTi-steel [10] in Table 1). For other steel grades containing similar $\mathrm{Nb}$ and $\mathrm{Ti}$ contents and various Mo content, similar or slightly higher strength and ductility were obtained here for up to 5.5 times lower Mo content after a more simple processing schedule (compare this work with [32 - 40] in Table 1). Our YS and UTS approached the values and El overcame the values obtained on a steel containing quite high contents of $\mathrm{Mn}, \mathrm{Ti}, \mathrm{Nb}$ and $\mathrm{V}$, namely $2.0 \mathrm{wt} . \% \mathrm{Mn}$ and $0.2(\mathrm{Ti}+\mathrm{Nb}+\mathrm{V})$, cooled at a very high cooling rate of $100 \mathrm{Cs}^{-1}$, which is difficult to achieve in industrial conditions (compare this work with [41] in Table 1). Our YS and UTS were $~ 150 \mathrm{MPa}$ higher and El was $\sim 1.5$ times higher than the values obtained on boron containing steels with similar amounts of other microalloying elements (compare this work with $[42,35]$ in Table 1). So remarkable improvements in mechanical properties are related to the following microstructural developments appearing as a result of processing using the $\mathrm{AC}^{2} \mathrm{WD}$-technology: grain size refinement, presence of deformation bands (reduced dislocation free pass), work hardening (high dislocation density), precipitation strengthening from particles formed in ferrite/bainite, and solid solution strengthening (in 
particular, from carbon). A possibility of TRIP effect, related in the NbTi-steel to presence of M/A constituent, requires further investigation.

In summary, the $\mathrm{AC}^{2} \mathrm{WD}$-technology allowed to obtain microalloyed steels with mechanical properties superior to those observed after conventional processing: (i) similar property values were achieved for steel compositions containing up to 6.6 times lower contents of microalloying elements after a shorter production cycle, namely reduced number of deformation stages; and (ii) in case of similar processing schedule, the strength was up to $200 \mathrm{MPa}$ higher with the same elongation for our steel containing 5 times lower amount of microalloying elements.

Table 1. Mechanical properties of $\mathrm{Ti}, \mathrm{Nb}, \mathrm{V}$ and Mo microalloyed steels

\begin{tabular}{|c|c|c|c|c|c|}
\hline $\begin{array}{c}\text { Steel composition, } \\
\text { wt. } \% \\
\end{array}$ & Processing & $\begin{array}{l}\text { YS, } \\
\mathrm{MPa} \\
\end{array}$ & $\begin{array}{l}\text { UTS, } \\
\mathrm{MPa}\end{array}$ & $\mathrm{El}, \%$ & Ref. \\
\hline \multicolumn{6}{|c|}{ cheap steel composition (Ti content increasing downwards) } \\
\hline \multirow{2}{*}{$0.095 \mathrm{C}-0.012 \mathrm{Ti}$} & $\mathrm{AC}^{2} \mathrm{WD}$ no holding & 627 & 771 & 27 & \multirow{2}{*}{$\begin{array}{l}\text { this } \\
\text { work }\end{array}$} \\
\hline & $\mathrm{AC}^{2} \mathrm{WD}$ holding & 686 & 783 & 24 & \\
\hline $0.041 \mathrm{C}-0.02 \mathrm{Ti}$ & $\begin{array}{c}13 \text { passes, } 0.14-0.29 \text { strain } \\
\text { per pass, } 1160-400{ }^{\circ} \mathrm{C}, \\
25 \mathrm{Cs}^{-1} \text { cooling rate }\end{array}$ & $508-700$ & $635-740$ & $\begin{array}{l}\text { no } \\
\text { data }\end{array}$ & {$[29]$} \\
\hline $0.003 \mathrm{C}-0.06 \mathrm{Ti}$ & $\begin{array}{c}3 \text { passes, } 0.63 \text { total strain, } \\
1100-750{ }^{\circ} \mathrm{C}, \\
\text { water quenching }\end{array}$ & $478-497$ & $557-571$ & $20-26$ & {$[30]$} \\
\hline $0.08 \mathrm{C}-0.08 \mathrm{Ti}$ & $\begin{array}{l}\text { finish rolling at } 850{ }^{\circ} \mathrm{C} \\
18 \mathrm{Cs}^{-1} \text { cooling rate }\end{array}$ & $645-685$ & $715-750$ & $20-24$ & [31] \\
\hline \multicolumn{6}{|c|}{ expensive steel composition (Mo content increasing downwards) } \\
\hline \multirow{2}{*}{$\begin{array}{c}0.081 \mathrm{C}-0.1 \mathrm{Mo}- \\
0.064 \mathrm{Nb}-0.021 \mathrm{Ti}\end{array}$} & $\mathrm{AC}^{2} \mathrm{WD}$ no holding & 820 & 993 & 21 & \multirow{2}{*}{$\begin{array}{l}\text { this } \\
\text { work }\end{array}$} \\
\hline & $\mathrm{AC}^{2} \mathrm{WD}$ holding & 880 & 1037 & 24 & \\
\hline $\begin{array}{c}0.081 \mathrm{C}-0.1 \mathrm{Mo}- \\
0.064 \mathrm{Nb}-0.021 \mathrm{Ti}\end{array}$ & $\begin{array}{c}0.35 \text { strain at } 1100{ }^{\circ} \mathrm{C}, \\
0.75 \text { strain at } 1075-825^{\circ} \mathrm{C}, \\
1 \mathrm{Cs}^{-1} \text { cooling rate }\end{array}$ & 404 & $498-603$ & $27-34$ & {$[10]$} \\
\hline $0.1 \mathrm{C}-0.15(\mathrm{Nb}+\mathrm{Ti})$ & $\begin{array}{l}7 \text { passes, } 900-800{ }^{\circ} \mathrm{C} \text {, } \\
11-30 \mathrm{Cs}^{-1} \text { cooling rate }\end{array}$ & $665-725$ & $730-775$ & $18-19$ & {$[32]$} \\
\hline $\begin{array}{c}0.075 \mathrm{C}-0.079 \mathrm{Mo}- \\
0.055 \mathrm{Nb}-0.06 \mathrm{Ti}\end{array}$ & $\begin{array}{l}\text { finish rolling at } 900{ }^{\circ} \mathrm{C}, \\
12-65 \mathrm{Cs}^{-1} \text { cooling rate }\end{array}$ & $619-731$ & $682-764$ & $17-19$ & [33] \\
\hline $\begin{array}{c}0.047 \mathrm{C}-0.20 \mathrm{Mo}- \\
0.082 \mathrm{Ti}\end{array}$ & $\begin{array}{l}\text { commercially produced, } \\
\text { finish rolling at } 900{ }^{\circ} \mathrm{C}\end{array}$ & 734 & 807 & 24 & {$[34]$} \\
\hline $\begin{array}{l}0.064 \mathrm{C}-0.22 \mathrm{Mo}- \\
0.031 \mathrm{Nb}-0.031 \mathrm{~V}\end{array}$ & $\begin{array}{c}0.55 \text { strain at } 1150-1050{ }^{\circ} \mathrm{C} \\
0.69 \text { strain at } 840-800{ }^{\circ} \mathrm{C} \\
19-24 \mathrm{Cs}^{-1} \text { cooling rate }\end{array}$ & $530-710$ & $770-880$ & $17-22$ & {$[35]$} \\
\hline $\begin{array}{c}0.09 \mathrm{C}-0.26 \mathrm{Mo}- \\
0.093 \mathrm{Ti}-0.14 \mathrm{~V}\end{array}$ & $\begin{array}{c}7 \text { passes, } 1200-780{ }^{\circ} \mathrm{C} \text {, } \\
15 \mathrm{Cs}^{-1} \text { cooling rate } \\
\end{array}$ & $815-955$ & $930-1000$ & $17-19$ & [36] \\
\hline $\begin{array}{c}0.075 \mathrm{C}-0.275 \mathrm{Mo}- \\
0.17 \mathrm{Ti}\end{array}$ & $\begin{array}{c}7 \text { passes, } 0.13 \text { strain per pass, } \\
1150-750{ }^{\circ} \mathrm{C} \\
20 \mathrm{Cs}^{-1} \text { cooling rate } \\
\end{array}$ & $722-907$ & $810-965$ & $23-28$ & {$[37]$} \\
\hline $\begin{array}{l}0.025 \mathrm{C}-0.32 \mathrm{Mo}- \\
0.039 \mathrm{Nb}-0.019 \mathrm{~V}\end{array}$ & $\begin{array}{c}7 \text { passes, } 0.20-0.36 \text { strain per } \\
\text { pass, } 1050-750{ }^{\circ} \mathrm{C} \\
20 \mathrm{Cs}^{-1} \text { cooling rate }\end{array}$ & $545-626$ & $627-716$ & $23-24$ & {$[38]$} \\
\hline
\end{tabular}




\begin{tabular}{|c|c|c|c|c|c|}
\hline $\begin{array}{c}0.041 \mathrm{C}-0.32 \mathrm{Mo}- \\
0.020 \mathrm{Ti}\end{array}$ & \multirow{2}{*}{$\begin{array}{l}13 \text { passes, } 0.14-0.29 \text { strain } \\
\text { per pass, } 1160-400{ }^{\circ} \mathrm{C} \\
25 \mathrm{Cs}^{-1} \text { cooling rate }\end{array}$} & $590-730$ & $700-750$ & $\begin{array}{l}\text { no } \\
\text { data }\end{array}$ & \multirow{2}{*}{ [29] } \\
\hline $\begin{array}{c}0.039 \mathrm{C}-0.28 \mathrm{Mo}- \\
0.068 \mathrm{Nb}-0.018 \mathrm{Ti}\end{array}$ & & $695-800$ & $780-835$ & $\begin{array}{c}\text { no } \\
\text { data }\end{array}$ & \\
\hline $\begin{array}{c}0.056 \mathrm{C}-1.97 \mathrm{Mn}- \\
0.41 \mathrm{Mo}-<0.13 \\
(\mathrm{Ti}+\mathrm{Nb}+\mathrm{V})\end{array}$ & $\begin{array}{l}\text { several passes, } 1125-700{ }^{\circ} \mathrm{C} \text {, } \\
\quad 30 \mathrm{Cs}^{-1} \text { cooling rate }\end{array}$ & $633-770$ & $725-880$ & $14-23$ & [39] \\
\hline $\begin{array}{c}0.052 \mathrm{C}-0.55 \mathrm{Mo}- \\
0.043 \mathrm{Nb}-1.76 \mathrm{Ni}- \\
1.08 \mathrm{Cu}\end{array}$ & $\begin{array}{c}\text { finish rolling at } 1000-800{ }^{\circ} \mathrm{C}, \\
\text { quenched and tempered }\end{array}$ & 890-902 & 924-966 & $20-24$ & [40] \\
\hline $\begin{array}{c}0.06 \mathrm{C}-2.0 \mathrm{Mn}- \\
0.2(\mathrm{Ti}+\mathrm{Nb}+\mathrm{V})\end{array}$ & $\begin{array}{c}5 \text { passes, } 0.36-0.48 \text { strain per } \\
\text { pass, } 1130-880{ }^{\circ} \mathrm{C}, \\
100 \mathrm{Cs}^{-1} \text { cooling rate }\end{array}$ & $820-956$ & $910-1021$ & $10-19$ & [41] \\
\hline $\begin{array}{c}0.08 \mathrm{C}-0.033 \mathrm{Nb}- \\
0.026 \mathrm{Ti}-0.058 \mathrm{~V}- \\
0.0024 \mathrm{~B}\end{array}$ & $\begin{array}{c}4 \text { passes, } 0.75 \text { total strain, } \\
1150-825^{\circ} \mathrm{C} \\
10 \mathrm{Cs}^{-1} \text { cooling rate }\end{array}$ & 640 & 860 & 18 & [42] \\
\hline $\begin{array}{c}0.053 \mathrm{C}-0.23 \mathrm{Mo}- \\
0.03 \mathrm{Nb}-0.031 \mathrm{~V}- \\
0.025 \mathrm{Ti}-0.0012 \mathrm{~B}\end{array}$ & $\begin{array}{c}0.55 \text { strain at } 1150-1050{ }^{\circ} \mathrm{C} \\
0.69 \text { strain at } 840-800{ }^{\circ} \mathrm{C} \\
19-24 \mathrm{Cs}^{-1} \text { cooling rate }\end{array}$ & $630-730$ & $830-860$ & $15-16$ & [35] \\
\hline
\end{tabular}

\section{Acknowledgement}

The authors are thankful to Bluescope Steel Ltd, Australia, for providing the test material. This work was financially supported by the Faculty of Engineering and Information Sciences, University of Wollongong. Personal thanks are expressed to Prof. Roger Lewis. Scanning electron microscopy was carried out using JEOL JSM-7001F FEGSEM (supported by grant LE0882613) at the Electron Microscopy Centre (UoW).

\section{References}

1. J.R. Stubbles, The Minimill Story, Metallurgical and Materials Transactions, 40B (2009) 134144.

2. D. Rosenthal, S. Kramer, C. Klein, C. Geerkens, J. Muller, 20 years of CSP: success story of an extraordinary technology, Stahl und Eisen 129(11) (2009) 73-89.

3. Y. Shimizu, J. Iwatani, J. Hasai, Compact hot strip mill for high quality strip production, Mitsubishi Heavy Industries Technical Review, 37(2) (2000) 48-51.

4. R. Wang, C. I. Garcia, M. Hua, K. Cho, H. Zhang, A. J. DeArdo: ISIJ Int. 46(9) (2006) 13451353.

5. S. Ge, M. Isac, R.I.L. Guthrie, ISIJ International, 52 (2012) 2109-2122.

6. N. Zapuskalov, ISIJ International, 43 (2003) 1115-1127.

7. Z.P. Xiong, A.G. Kostryzhev, N.E. Stanford, E.V. Pereloma, Materials and Design 88 (2015) 537-549.

8. Z.P. Xiong, A.G. Kostryzhev, A.A. Saleh, L. Chen, E.V. Pereloma, Materials Science and Engineering A664 (2016) 26-42.

9. Z.P. Xiong, A.G. Kostryzhev, N.E. Stanford, E.V. Pereloma, Materials Science and Engineering A651 (2016) 291-305.

10. A.G. Kostryzhev, O.O. Marenych, C.R. Killmore, E.V. Pereloma, Metallurgical and Materials Transactions A 46(8) (2015) 3470-3480. 
11. A. Al Shahrani, The effects of niobium segregation and dynamic recrystallisation on microstructural homogeneity of microalloyed steels, $\mathrm{PhD}$ thesis, University of Wollongong, Australia, 2013. http://ro.uow.edu.au/theses/4005

12. A.G. Kostryzhev, A. Al Shahrani, C. Zhu, S. P. Ringer and E. V. Pereloma, Material Science and Engineering A 581 (2013) 16-25.

13. J.S. Park, Y.K. Lee, Scripta Materialia 57 (2007) 109-112

14. X. Li, Z. Wang, X. Deng, Y. Li, H. Lou, G. Wang, Materials Letters 182 (2016) 6-9.

15. A. Iza-Mendia, M.A. Altuna, B. Pereda, I. Gutierrez, Metallurgical and Materials Transactions A 43 (2012) 4553-4570.

16. X. Wang, Y. Zhao, B. Liang, L. Du, H. Di, Steel Research Int. 84(4) (2013) 402-409.

17. R. Song, N. Fonstein, H. J. Jun, N. Pottore, D. Bhattacharya, S. Jansto, Metallogr. Microstruct. Anal. 3 (2014) 174-184.

18. R. Soto, W. Saikaly, X. Bano, C. Issartel, G. Rigaut and A. Charai, Acta Materialia 47(12) (1999) $3475-3481$.

19. R.D.K. Misra, H. Nathani, J.E. Hartmann, F. Siciliano, Material Science and Engineering A 394 (2005) $339-352$.

20. S.W. Ooi, G. Fourlaris, Materials Characterization 56 (2006) 214-226.

21. H.I. Aaronson, W.T. Reynolds, Jr., G.R. Purdy, Metallurgical and Materials Transactions A 37 (2006) 1731-1745.

22. E.S. Humphreys, H.A. Fletcher, J.D. Hutchins, A.J. Garratt-Reed, W.T. Reynolds, Jr., H.I. Aaronson, G.R. Purdy, G.D.W. Smith, Metallurgical and Materials Transactions A 35 (2004) $1223-1235$.

23. B. Mintz, J. R. Banerjee, K. M. Banks, Ironmaking and Steelmaking 38(3) (2011) 197-203.

24. Y.-K. Lee, J.-M. Hong, C.-S. Choi, J.-K. Lee, Materials Science Forum 475-479 (2005) 6568.

25. Y. Chen, D. Zhang, Y. Liu, Huijun Li, Dakun Xu, Materials Characterization 84 (2013) 232 $-239$.

26. K.R. Carpenter, C.R. Killmore, Metals 5 (2015) 1857-1877.

27. R.W. Cahn: Physical Metallurgy, North-Holland Publishing, Amsterdam, 1970.

28. F.C. Frank and W.T. Read: Phys. Rev. Lett. 79 (1950) $722-723$.

29. S.H. Mousavi Anijdan, S. Yue, Metallurgical and Materials Transactions A, 43 (2012) 11401162.

30. R. Shukla, S.K.Ghosh, D.Chakrabarti, S.Chatterjee, Materials Science and Engineering A 587 (2013) 201-208.

31. H-L. Yi, Z-Y. Liu, G-D. Wang, D. Wu, Journal of Iron and Steel Research International 17(12) (2010) 54-58.

32. J. Hu, L-X. Du, J.-J. Wang, Materials Science and Engineering A 554 (2012) 79 - 85.

33. S. Tang, Z.Y.Liu, G.D.Wang, R.D.K. Misra, Materials Science and Engineering A 580 (2013) 257-265.

34. Y. Funakawa, T. Shiozaki, K. Tomita, T. Yamamoto, E. Maeda, ISIJ International, 44(11) (2004) 1945-1951.

35. X. Kong, L. Lan, Z. Hu, B. Li, T. Sui, Journal of Materials Processing Technology 217 (2015) 202-210.

36. K. Zhang, Z-D. Li, X-J. Sun, Q-L. Yong, J-W. Yang, Y-M. Li, P-L. Zhao, Acta Metall. Sin. (Engl. Lett.) 28(5) (2015) 641-648.

37. Y. W. Kim, J. H. Kim, S.-G. Hong, C. S. Lee, Materials Science and Engineering A 605 (2014) 244-252.

38. W. Wang, W. Yan, L. Zhu, P. Hu, Y. Shan, K. Yang, Materials and Design 30 (2009) 34363443. 
39. S. Nafisi, M.A. Arafin, L. Collins, J. Szpunar, Materials Science and Engineering A 531 (2012) 2- 11.

40. S.K. Dhua, S.K. Sen, Materials Science and Engineering A 528 (2011) 6356-6365.

41. E. J. Chun, H. Do, S. Kim, D-G. Nam, Y-Ho Park, N. Kang, Materials Chemistry and Physics 140 (2013) $307-315$.

42. P.C.M. Rodrigues, E.V. Pereloma, D.B. Santos, Materials Science and Engineering A 283 (2000) 136-143. 